\title{
EESTI JA SOOME SÕNALUGEMISTESTIDE VõRDLUS
}

\author{
Piret Soodla, Maigi Vija, Renate Pajusalu
}

Ülevaade. Artiklis analüüsitakse kahte lugemistesti - sõnaloendi lugemise testi ja sõnade äratundmise testi - võrdlevalt eesti ja soome keeles. Uurimusel on kaks eesmärki: hinnata nimetatud testide eesti-ja soomekeelsete versioonide omavahelist vastavust ja arendada lugemistestide võrdlemise meetodeid. Testide võrdlemisel rakendatakse paralleelselt testide keelelist analüüsi, täiskasvanud lugejate testitulemuste ning laste testisoorituste ja intervjuude analüüsi. Tulemused osutavad nimetatud testide suurele sarnasusele. Teste ei saa siiski pidada identseteks eesti ja soome keeles, seda osalt mõningaste erinevuste tõttu testides endas ning osalt keeleliste iseärasuste tõttu.

Võtmesõnad: testimine, hindamine, lugemisoskus, eesti keel, soome keel

\section{Sissejuhatus}

Lugemaõppimine on üks olulisematest ülesannetest esimestel kooliaastatel. Lugemise peamine eesmärk on loetu mõistmine, mis võimaldab saada teavet, kogeda teisi (kujuteldavaid) maailmu, edukalt suhelda ning õppida. Lugemisraskused on üheks sagedamaks õpiraskuste tekkepõhjuseks - peaaegu kõik õppeained koolis nõuavad teatud lugemisoskuse taset. Kui lapsel esineb eakohase teksti mõistmisel raskusi, võivad selle põhjused olla erinevad. Sobiva õpiabi pakkumiseks tuleb esmalt välja selgitada mõistmisraskuse põhjus. Laste lugemisoskuse jälgimisel ja hindamisel on olulised õpetaja argitähelepanekud, kuid lisaks soovitatakse kasutada eri tüüpi lugemisteste. Praegusel ajal napib Eestis usaldusväärseid vahendeid õpilaste vaimsete võimete, akadeemiliste ja sotsiaalsete oskuste hindamiseks - kasutusel on neid küll rohkesti, kuid valdavalt on tegemist üliõpilastööde raames koostatud või teistest keeltest tõlgitud testidega, mille sobivust ei ole kontrollitud esinduslike valimitega (Kikas 2006). Sarnane on Eesti hetkeolukord ka lugemisoskuse hindamise vahendite vallas, samal ajal kui näiteks Soomes on laste lugemisoskuse hindamiseks

* Artikkel on valminud Euroopa Sotsiaalfondi programmi Eduko alamprojekti nr. 30.2-10.2/1247, Eesti Teadusfondi 
kasutusel mitmeid standardiseeritud testipakette (vt Lerkkanen 2007: 150-155). Laste oskuste hindamisvahendite vajadusele on viidanud ka Eesti teadusuuringud (Soodla 2012, Soodla, Kikas 2010).

Viimastel aastatel on mitme uurimisprojekti ${ }^{1}$ raames koostatud ja kasutatud eesti algklassiõpilaste lugemisoskuse hindamise vahendeid, millest mõne puhul on aluseks võetud Soomes kasutatavad materjalid. Siinses artiklis analüüsitakse kahe lugemistesti - sõnaloendi lugemise testi ja sõnade äratundmise testi - eestikeelset ja soomekeelset varianti. Testide võimalikult suur sisuline ja keeleline sarnasus võimaldaks neid kasutada analoogsete hindamisvahenditena keeltevahelistes uuringutes, mille osatähtsus on viimastel aastatel haridusvaldkonnas oluliselt tõusnud. Ideaalis peaksid võrdlusuuringutes kasutatavad hindamisvahendid olema statistiliselt identsed keskmise tulemuse, standardhälbe ning vigade struktuuri poolest. Praktikas on testide statistilist identsust saavutada siiski ülimalt keerukas, kui mitte võimatu (Arffman 2010).

Võrreldavad andmed eesti ja soome laste lugemisoskuse arengu kohta võimaldavad teha järeldusi lugemaõppimise ja -õpetamise kohta suhteliselt reeglipärase ortograafiaga keeltes. Siinse uurimuse kitsam eesmärk ongi hinnata sõnaloendi lugemise testi ja sõnade äratundmise testi eesti- ja soomekeelsete versioonide omavahelist vastavust, rakendades meetoditriangulatsiooni ${ }^{2}$ : testide keelelist analüüsi, täiskasvanute testitulemuste ning laste testisoorituste ja intervjuude analüüsi. Laiem eesmärk on aga aidata kaasa üldise lugemistestide pädeva võrdlemise meetodi väljatöötamisele.

\section{Lugemaõppimine eri keeltes}

Kirjaliku teksti mõistmine on keerukas kognitiivne toiming, mis hõlmab palju erinevaid osaoskusi ja protsesse. Loetu mõistmine on kahe oskuste rühma - sõnade lugemise ja kuuldu mõistmise - tulemus (Hoover, Gough 1990). Sõna lugemine hõlmab dekodeerimist ehk tähtede ja nende kombinatsioonide "tõlkimist" häälduseks ning sõna äratundmist ehk kirjutatud sõna kokkuviimist selle tähendusega. Kuuldu mõistmise all peetakse silmas protsesse, mis tagavad sõnumi mõistmise lause- ja tekstitasandil. Siinses uurimuses analüüsime sõnade lugemisoskuse hindamisvahendeid.

Sõnade lugemise oskus - lugemise õigsus ja kiirus - on loetu mõistmisega oluliselt seotud: korrelatsioonid eri uuringutes on mõõdukad kuni tugevad. Lugemistehniliste oskuste paranedes väheneb dekodeerimisoskuse mõju teksti mõistmisele ning üha olulisemaks muutuvad sõnavara ja nn kõrgema tasandi oskused - järeldamine, integreerimine, metalingvistilised oskused ja teksti struktuuri tundmine; vabanevad ka ressursid, mida kasutatakse kõrgema tasandi mõistmisprotsesside rakendamiseks. (Perfetti 1994: 878, Oakhill, Cain 2007, Priya, Wagner 2009). Siiski näitab ka mõõdukas seos sõnade lugemise ja loetu mõistmise vahel, et suurel osal tehniliste lugemisraskustega lugejatest on probleeme ka kirjaliku teksti mõistmisega.

Sõnade lugemisele avaldab otsest mõju lugemismaterjali keerukus - sõna sagedus keeles ja sõna pikkus. Keeles harva esinevate sõnade lugemisel peatub pilk

1 Eesti Teadusfondi grandid 7388 ja 9101, Eesti Sotsiaalfondi programmi Eduko projekt nr 30.2-10.2/1247.

2 Sotsiaalteadustes määratletakse triangulatsiooni kui "kahe või enama meetodi kasutamist inimkäitumist puudutavate andmete kogumiseks" (Cohen jt 2001: 112). Ühe nähtuse uurimisel lähenetakse sellele erinevatelt teoreetilistelt seisukohtadelt, kasutades kvalitatiivseid ja/või kvantitatiivseid meetodeid. See võimaldab hõlmata nähtust mitmekülgsemalt ja täielikumalt ning tagab ka suurema valiidsuse. 
sõnaosadel kauem ja rohkem kordi ning ka lugemisvigade (sõnaosade või sõnade asendamine, moonutamine, lugemata jätmine, lisamine) hulk on oluliselt suurem kui tuttavate sõnade lugemisel. Sarnaseid tulemusi on saadud tähendusega sõnade ja tähenduseta sõnade lugemise uurimisel: viimaste lugemine on vigaderohkem ja aeglasem. Lugemise tulemust mõjutab ka sõna pikkus - mida pikem on sõna, seda rohkem lugeja pilk selle eri osadel peatub ning seda kauem võtab sõna äratundmine aega. (Hyönä, Olson 1995, De Luca jt 2002, Hutzler, Wimmer 2004, Dürrwächter jt 2010). Sõnade sageduse ja pikkuse mõju lugemise õigsusele ja kiirusele on täheldatud eri vanuses lugejate ning nii eakohase kui ka puuduliku lugemisoskuse puhul, olles eriti tugev just viimasel juhul.

Lugemaõppimise ja -õpetamise juures on tähtis roll ka vastava keele kirjaviisil. Alfabeetilise kirjasüsteemiga keelte võrdlemisel on leitud, et lugemisoskuse kujunemist ja omandamise kiirust mõjutab oluliselt keele ortograafia reeglipärasus ehk tähe-hääliku vastavus. Reeglipärase ortograafiaga keeltes (nt soome, saksa) toimub lugemaõppimine oluliselt kiiremini kui ebareeglipärase kirjasüsteemiga keeltes (nt inglise, taani, prantsuse) (Aro, Wimmer 2003, Seymour jt 2003). Reeglipärase ortograafiaga keeltes on lugemisvigade periood suhteliselt lühike ning lugemisraskused seostuvad eelkõige lugemise kiiruse, mitte niivõrd õigsusega (Aro 2004: 21, Landerl, Wimmer 2008). Teise võimaliku keelespetsiifilise mõjutegurina on Philip Seymour jt (2003) välja toonud keele fonoloogia, täpsemalt silbistruktuuri keerukuse: keeltes, kus on palju lahtisi silpe (nt itaalia, hispaania), on lapsed (mittesõnade) lugemises edukamad kui keeltes, mille sõnadele on iseloomulik kinniste silpide ja konsonantühendite rohkus (nt saksa, taani, inglise).

\section{Eesti ja soome keele ortograafia ning silbistruktuuri põhijooned}

Eesti ja soome keel on lähisugulaskeeled ja nende ortograafia on põhimõtteliselt sarnane: mõlema keele kiri on alfabeetiline ja järgib võrreldes paljude teiste keeltega suhteliselt hästi printsiipi üks häälik - üks täht. Eesti kirjakeeles on 23 tähte ja 24 foneemi, soome keeles 21 tähte ja 21 foneemi ${ }^{3}$ (eesti keele kohta vt EKK 2007: 49-54, Hint 2004: 74, soome keele kohta vt Aro 2004: 14, Hakulinen jt 2004: 37-42). Mõlemas keeles on siiski ka kõrvalekaldumisi printsiibist üks häälik üks täht. Näiteks ei erista kumbki keel kirjapildis häälikuid /n/ ja /y/. Nii eesti kui soome keeles võib võõrsõnades häälikute pikkus häälduses erineda kirjapildi järgi oletatust (sm arkeologia [arkkeologia], ee apelsin [apelsiin]). Soome keeles ei märgita kirjas piirigeminatsiooni (sinnekään [sinnekkään]), mida eesti keele hääldamises esineb palju vähem.

Eesti keeles on mittevastavust fonoloogilise ja ortograafilise süsteemi vahel siiski rohkem kui soome keeles. Kui soome keele ortograafia kohta on öeldud, et see on lugemaõppimise seisukohalt optimaalne (Aro 2004: 16), siis ei saa sama öelda eesti keele kohta, kus kirjutatud kujul pole võimalik vahet teha pikal ja ülipikal häälikul (v.a sulghäälikud), konsonantühendil ega diftongil. Teine oluline mittevastavus eesti ortograafilise ja häälikusüsteemi vahel on palatalisatsiooni mittemärkimine (nt kirjapilt palk võib olla hääldatud [palk] ja [pal' k]). Ortograafia ei kajasta kummaski keeles sõnarõhku, mis soome keeles on alati esimesel silbil, kuid eesti võõrsõnade

3 Võõrsõnatähti ja vastavaid foneeme arvestamata. 
lugemisel võib raskendavaks asjaoluks olla see, et mõnikord on rõhk ka järgsilbil. Selle põhjal võiks oletada, et eesti keelt on raskem lugema õppida kui soome keelt.

Eesti ja soome silbistruktuur on põhijoontes sarnane (soome k kohta vt Aro 2004: 14). Kummalegi ei ole algupäraselt omased konsonantühendid silbi alguses, kuid eesti keeles on neid siiski ka vanemates laensõnades, samas kui soome keeles ainult päris uutes võõrsõnades (ee $\boldsymbol{k l}$ laas, traav, sm lasi, ravi, aga ee traditsioon, sm traditio). Siinse artikli seisukohalt on oluline lahtiste ja kinniste silpide vahekord keeles, kuna viimaseid arvatakse olevat raskem lugeda (Seymour jt 2003). ${ }^{4}$ Eesti keeles on soome keelega võrreldes kinniseid silpe ajaloolise arengu tõttu tõenäoliselt rohkem, neid on tekitanud lõpukadu (ee madal, sm matala) ja sisekadu (ee kandnud, sm kantanut), teiselt poolt on sõnalõpulise $n$-i kadu eesti keeles tekitanud mõnedesse vormidesse lahtiseid silpe just juurde (ee jõkke, sm jokeen). (Ajalooliste muutuste mõjust võrdlevalt eesti ja soome keelele vt nt Remes 2009: 50-56.) Teadaolevalt ei ole võrdlevat statistilist uurimust kinniste ja lahtiste silpide sageduse kohta eesti ja soome keeles tehtud, ${ }^{5}$ kuid võib siiski oletada, et soome (kirja)keeles on lahtisi silpe rohkem.

Nii eesti kui soome keeles on lugemaõppimist raskendavaks faktoriks keerukas morfoloogia: sõnadel on mitmeid eri tüvesid, vormid on tihti väga pikad (soome keeles pikemadki kui eesti keeles) ja sõna äratundmine seetõttu raskendatud.

\section{Lugemistestid - mida ja kuidas hinnata?}

Lugemisega seotud oskuste hindamine on oluliseks lapse arengu toetamise vahendiks nii enne kooli kui ka koolieas. Lugemisoskust hinnatakse erinevatel eesmärkidel: lapse individuaalse arengu jälgimiseks, võimaliku lugemisraskuse, selle sügavuse ja põhjuse väljaselgitamiseks, tagasisideks õpetuse efektiivsuse kohta ning õpetuse planeerimiseks. Kuna lugemisoskus hõlmab erinevaid kognitiivseid oskusi, on vajalik määratleda, mida täpsemalt hinnata soovitakse: sõnade lugemise eeloskusi, lugemistehnilisi oskusi, funktsionaalset lugemisoskust vm. Artiklis anname ülevaate sõnade lugemise oskuse hindamise võimalustest.

Sõnade lugemisoskuse hindamise eesmärkideks on välja selgitada dekodeerimise õigsus (st võimalike lugemisvigade tüübid ja sagedus), juhtiv lugemisviis, lugemise kiirus ja/või sõnade äratundmise oskus. Kui ebareeglipärase ortograafiaga keeltes peetakse oskuse hindamisel oluliseks õigsust, siis reeglipärase kirjasüsteemiga keeltes rõhutatakse sõnade lugemise kiiruse hindamist (Cain 2010: 201).

Dekodeerimisoskuse mõõtmiseks kasutatakse sageli teksti(lõigu), sõna- või mittesõnade loendite lugemist (nt Landerl, Wimmer 2008). Kõikide nende meetodite puhul on vajalik individuaalne testimine, lugemine toimub häälega ning hinnata on võimalik lugemise õigsust ja kiirust. Sõnade äratundmise oskuse mõõtmiseks võib kasutada sõnaketi meetodit (nt Tong jt 2011), kus lugejal tuleb mingi aja jooksul võimalikult kiiresti eraldada sõnad kokkukirjutatud sõnade jadast, või sõna ja pildi ühendamise ülesannet (nt Torppa jt 2007), mis nõuab valikuks antud sõnade hulgast pildile vastava sõna leidmist. Sõnade äratundmise teste saab läbi viia rühmas või individuaalselt, hääletult või häälega lugedes.

\footnotetext{
4 Omaette seni uurimata probleem on seegi, kas eesti keeles kirjapildis lahtine, kuid häälduses kinnine silp (lühikese klusiilgeminaadiga sõnades nt esisilbid sõnades lõpu, soki, koti) on lugemaõppimise seisukohalt pigem kergem või raskem variant. Kirjapilt on sel juhul nagu lihtsate lahtiste silpide puhul ja väga võimalik, et häälduslik gemineerimine ei avalda tegelikult mingit mõju.

5 Eesti ilukirjanduskeele silbistruktuurielementide fonostatistilise ülevaate on koostanud Mati Hint (1988), keskendudes silbi järjekorranumbri ning silbi koostisosade (silbialgus, -tuum ja -lõpp) seostele.
} 
Viimasel aastakümnel on oluliselt tõusnud rahvusvaheliste uurimuste osakaal haridusvaldkonnas. Taoliste uurimuste juures on väga oluline, et õpilaste oskuste hindamise vahendid oleksid sisuliselt ja keeleliselt võimalikult sarnased. Siinses artiklis kirjeldame kahte eesti- ja soomekeelset sõnalugemistesti ning tutvustame testide võrdlemise meetodit.

\section{Meetod}

\subsection{Materjal: sõnaloendi lugemise test ja sõnade äratundmise test}

Sõnaloendi lugemise testi soomekeelne variant kuulub Soome standardiseeritud testipaketti Lukilasse (Häyrinen jt 1999), eestikeelse testi on koostanud Piret Soodla ja Inna Marats. Test koosneb kolme veergu paigutatud 90 sõnast, mis on järjestatud sõna häälik- ja silbistruktuuri keerukusastme tõusu põhimõttel: testi esimesed sõnad on lihtsa struktuuriga ühe- ja kahesilbilised sõnad (nt ee ema, lai, nüüd, sm eli, soi, jäät), järgnevad pikemad ja keerulisema silbistruktuuriga sõnad ja võõrsõnad (nt ee märkavad, vabaajarõivastus, mikroskoobid, sm markkinat, kotitalouskoneet, mikroskooppi). Test viiakse läbi individuaalselt. Ülesanne on sõnu võimalikult kiiresti häälega lugeda 45 sekundi jooksul. Testi sooritamise ajal märgib testija üles õigesti ja valesti loetud ning vahele jäetud sõnad. Sõnaloendi lugemise test võimaldab hinnata dekodeerimise õigsust ja kiirust.

Sõnade äratundmise testi soomekeelne variant kuulub Soome testipaketti Alaasteen lukutesti (Lindeman 1998), eestikeelse versiooni koostas Piret Soodla. Test koosneb 80 pildist ja 320 sõnast. Iga pildi juures on neli sarnase häälikkoostisega sõna, millest üks vastab pildile (nt pilt 'tigu'- sõnad tegu, tibu, tigu, tina). Testisõnad on järjestatud häälik-ja silbistruktuuri keerukusastme tõusu põhimõttel: testi alguses on sõnad lihtsamad (nt ee kuu, tibu, sm kuu, pupu), testi edenedes muutuvad sõnad pikemaks ja struktuurilt keerukamaks (nt ee võtmed, kummirõngas, dinosaurus, sm farkut, kumipatja, dinosaurus). Testi saab läbi viia nii rühmas kui ka individuaalselt, sõnu loetakse hääletult. Ülesanne on kahe (soome originaalvariandis viie) minuti jooksul ühendada joonega võimalikult palju pilte sobiva sõnaga. Testi sooritust näitab õigesti ja valesti ühendatud ning ühendamata jäetud sõnade hulk. Testi abil saab hinnata sõnade äratundmise õigsust ja lugemiskiirust.

\subsection{Testide võrdlemise protseduur}

Sõnalugemistestide raskusaste võib tuleneda mitmest asjaolust, mida tuleb arvestada nii sama- kui erikeelsete testide võrdlemisel. Esmatähtis on see, mis oskust või oskuste rühma testiga hinnatakse: kas hinnatakse dekodeerimise õigsust, kiirust ja/või sõnade äratundmist. Teiseks on oluline sõnade tuttavus, sest keeles sagedamad sõnad tuntakse lugemisel kiiremini ära. Laste testide puhul oleks relevantne võrrelda sõnade sagedust nendes tekstides, mida lapsed tegelikult loevad (lasteraamatud, õpikud, veebileheküljed, filmide subtiitrid), kuid selline sagedusloend meil paraku puudub ja sõnade sageduse hindamiseks tuleb kasutada olemasolevaid korpusi. Kolmas faktor on loetavate sõnade struktuur: kas tegemist on liht- või liitsõnadega, milline on sõnade häälik- ja silbistruktuur jms. Samuti võib oluline olla, 
millisel alusel eristuvad sõnavaliku testis valed variandid (segajad), sest ilmselt on raskem valida häälikuliselt sarnaste kui täiesti erinevate sõnade vahel. Lõpuks ei ole vähetähtis ka testi vormistuslik külg: kas loetavad sõnad on esitatud trüki- või kirjatähtedega, kas on esitatud silbipiirid jms, piltidega testis on oluline ka piltide kvaliteet. Lisaks testide endi võrdlemisele on võimalik võrrelda eri vanuserühmade lugemissooritusi.

Kahe kirjeldatud eesti- ja soomekeelse lugemistesti omavahelise vastavuse analüüsil rakendasime mitut meetodit. Esiteks võrdlesime testisõnade koostist, et selgitada, kuivõrd sarnased on eesti ja soome testid keeleliselt. Teiseks kontrollisime testide võrreldavust eesti ja soome üliõpilaste testitulemuste põhjal, et selgitada välja, kuidas õnnestub testi tegemine neil, kellel eeldatavasti ei tohiks enam lugemisraskusi olla. Kolmandaks viisime sõnade äratundmise testi läbi eesti ja soome lastega intervjuuna, milles küsisime, millised testisõnad ja -pildid võivad lastele raskusi valmistada ja mis võib olla selle põhjuseks.

\subsubsection{Testisõnade keeleline analüüs}

Selleks, et võrrelda eesti- ja soomekeelsete sõnalugemistestide keelelist külge, analüüsisime mõlema testi sõnade esinemissagedust keeles, sõnade pikkust, silbija häälikstruktuuri. Esinemissageduse määramiseks tegime kindlaks, mitmendal kohal on vastav sõna sagedussõnastikus lemmade sagedusloendis. ${ }^{6}$ Testisõnade pikkuse määrasime tähtede, silpide ja liitsõnaosade arvu põhjal. Testisõnade silbistruktuuri iseloomustamiseks silbitasime sõnad kirjapildist lähtuvalt ning arvutasime kokku lahtised häälikuühendita silbid (V, CV, CVıVı), kinnised häälikuühendita silbid ( $\mathrm{VC}, \mathrm{CVC}, \mathrm{CV}_{\mathrm{V}} \mathrm{C} C$ ) ja häälikuühendit (konsonantühendit ja diftongi) sisaldavad silbid mõlemas testis. Sõnade häälikstruktuuri analüüsides lugesime kokku häälikuühendid sõnas ning tegime kindlaks, kas häälikupikkus varieerub pildile vastava sõnarühma sees (sõnade äratundmise testis). Nimelt lugesime kokku sõnarühmad, mille lugemisel on õige sõna valiku kriteeriumiks häälikupikkus (nt eesti testis pilt 'kassid'- sõnad kassad, kaasad, kasid, kassid; soome testis pilt 'vaip' (sm matto) - sõnad mato, matto, mutta, musta). ${ }^{7}$

\subsection{2. Üliõpilaste testimine}

Sõnaloendi lugemise testi sooritasid 60 eesti keelt ja soome keelt emakeelena kõnelevat üliõpilast. Eesti üliõpilased ( $n=30,15$ meest ja 15 naist, keskmine vanus 23,5 a) õppisid testimise perioodil erinevatel erialadel eri Eesti ülikoolides. Soome üliõpilased ( $n=30$, kümme meest ja 20 naist, keskmine vanus 26,1 a) õppisid erinevatel erialadel Soome ja Eesti ülikoolides. Eesti üliõpilastega viidi läbi eestikeelne, soome üliõpilastega soomekeelne test. Testimise protseduur oli mõlemas keelerühmas samasugune: testimisele eelnes juhis, test viidi läbi individuaalselt, ajalimiit oli 45 sekundit. Sooritused salvestati diktofonile ning hiljem kodeeriti testitulemused (loetud sõnade koguhulk, õigesti ja valesti loetud sõnade arv).

Sõnade äratundmise test viidi läbi 58 üliõpilasega. Eesti üliõpilased olid samad, kes sooritasid sõnaloendi lugemise testi. Soome üliõpilased $(n=28$, viis meest ja

6 Ainus võrreldav materjal sõnade esinemissageduse võrdlemiseks eesti ja soome keeles on ajakirjanduskorpuse põhjal tehtud sagedussõnastikud, vt Eesti kirjakeele sagedussõnastik: http://www.cl.ut.ee/ressursid/sagedused1// (20.09.2012) ja Suomen sanomalehtikielen taajuussanasto: http://www.csc.fi/tutkimus/alat/kielitiede/ taajuussanasto-B9996/view (20.09.2012).

7 Andmete statistilisel analüüsil on olulisuse nivoo 0,05. 
23 naist, keskmine vanus 24,0 a) õppisid erinevatel erialadel Eesti ja Soome ülikoolides. Testimisele eelnes mõlemas keeles ühesugune juhis, testi sooritamiseks oli kaks minutit, eesti üliõpilastega viidi test läbi individuaalselt, soome üliõpilastega rühmas. Peale testi sooritamist kodeeriti tulemused (loetud sõnade koguhulk, õigesti ja valesti loetud sõnad ning ühendamata pildi-sõna paarid).

\subsubsection{Laste testimine ja intervjueerimine}

Sõnade äratundmise test intervjuuna viidi läbi eesti ja soome lastega. Eesti lapsi oli kokku viis: Peep $^{8}$ (1. kl, vanus 8 a), Iti (1. kl, 8 a), Ats (2. kl, 8 a), Hans (3. kl, 9 a) ja Kati (5. kl, 11 a). Soome lapsi oli neli: Jussi (3. kl, 9 a), Henna (3. kl, 9 a), Marja (5. kl, 11 a), Oskari (6. kl, 11 a). Testi läbiviimise käik erines eelpool kirjeldatust (vt 5.1) - lastel paluti sõnad valjusti ette lugeda ning iga pildi-sõna paari ühendamise järel küsis testija, miks laps just selle sõna valis ning kas mõni teine valikuks antud sõna võiks veel pildiga kokku sobida. Lastel lubati testi teha neile sobivas tempos, ajapiirangut ei rakendatud. Intervjuud lindistati diktofonile ning transkribeeriti.

\section{Tulemused}

\subsection{Sõnaloendi lugemise test}

\subsubsection{Testisõnade keeleline analüüs}

Eesti- ja soomekeelse testi 90 sõnast oli sagedussõnastikes esindatud vastavalt 43 ja 46 sõna. Testisõnade sagedusi keeltes võrdlesime kahe meetodiga. Esmalt võrdlesime eesti ja soome testi sõnu nende keskmise järjekorranumbri alusel sagedussõnastikes (t-testi abil). Analüüs näitas sõnade keskmise sageduse sarnasust eesti $(M=3240,8 ; S D=2920,2)$ ja soome testis $(M=3613,1 ; S D=3159,9), t(87)=0,58$, $p=0,57$. Järgmisena jaotasime testisõnad sageduse alusel viide kategooriasse: sõnad, mille järjekorranumber sõnastikus oli vahemikus 1) 1-100, 2) 101-500, 3) 501-1000, 4) 1001-5000, 5) üle 5000 (vt tabel 1, kategooriad K1-K5). Testisõnade jaotumist vastavatesse kategooriatesse analüüsisime Pearsoni hii-ruuttestiga, mis näitas, et sõnad jaotusid kategooriatesse sarnaselt, $\chi^{2}(4)=2,04 ; p=0,73$.

Tabel 1. Eesti- ja soomekeelsete sõnalugemistestide sõnade jaotumine kategooriatesse sageduse alusel

\begin{tabular}{|l|l|c|c|c|c|c|c|}
\hline \multirow{2}{*}{ Test } & \multirow{2}{*}{ Testi keel } & \multicolumn{5}{|c|}{ Sõnade arv ja osakaal protsentides } & \multirow{2}{*}{ Kokku } \\
\cline { 2 - 7 } & & K1 & K2 & K3 & K4 & K5 & \\
\hline \multirow{2}{*}{$\begin{array}{l}\text { Sõnaloendi } \\
\text { lugemise test }\end{array}$} & eesti & $2(5 \%)$ & $6(14 \%)$ & $3(7 \%)$ & $21(49 \%)$ & $11(26 \%)$ & $43(100 \%)$ \\
\cline { 2 - 7 } & soome & $3(7 \%)$ & $5(11 \%)$ & $5(11 \%)$ & $17(37 \%)$ & $16(35 \%)$ & $46(100 \%)$ \\
\hline \multirow{2}{*}{$\begin{array}{l}\text { Sõnade ära- } \\
\text { tundmise test }\end{array}$} & eesti & - & $7(11 \%)$ & $2(3 \%)$ & $26(43 \%)$ & $26(43 \%)$ & $61(100 \%)$ \\
\cline { 2 - 7 } & soome & - & $2(4 \%)$ & $1(2 \%)$ & $28(60 \%)$ & $16(34 \%)$ & $47(100 \%)$ \\
\hline
\end{tabular}

Tähised: K1 = sõna järjekorranumber sagedussõnastikus vahemikus 1-100, K2 = sõna järjekorranumber sagedussõnastikus vahemikus 101-500, K3 = sõna järjekorranumber sagedussõnastikus vahemikus 501-1000, K4 = sõna järjekorranumber sagedussõnastikus vahemikus 1001-5000, K5 = sõna järjekorranumber sagedussõnastikus > 5000 .

8 Kõigi laste nimed on artiklis muudetud. 
Testisõnadest, mida sagedussõnastikus ei leidunud, on üks osa selliseid, mis on laste jaoks kindlasti tuttavad (nt ee puru, kilkab, vannitab, kõrvitsad; sm vaari, puuro, sääri, lakritsi), teine osa sõnadest on keeles suhteliselt harva esinevad (nt ee taimetoitlus, padrikus, vingerdus; sm vingahdus, kettingit, graniittilouhos). Lisaks leidus testisõnade hulgas pärisnimesid (ee testis Anu, Kalle, Aafrika, Austraalia; sm testis Esa, Kalle, Afrikka, Australia), mis võivad laste jaoks tuttavad olla, kuid mida eesti sagedussõnastik ei sisalda, soome sagedussõnastik aga sisaldab.

Testisõnade pikkust võrdlesime tähtede, silpide ja sõnaosade arvu alusel. Keskmine tähtede arv eesti ja soome sõnades oli väga sarnane: eesti testis $8,6(S D=3,7)$ ja soome testis $8,6(S D=3,8), t(178)=0,06 ; p=0,95$. Silpide arv sõnades varieerus mõlema testi puhul vahemikus $1-7$ ning ka sõnade jaotumine silpide arvu alusel oli testides sarnane (vt joonis 1$), \chi^{2}(6)=1,38 ; p=0,97$.

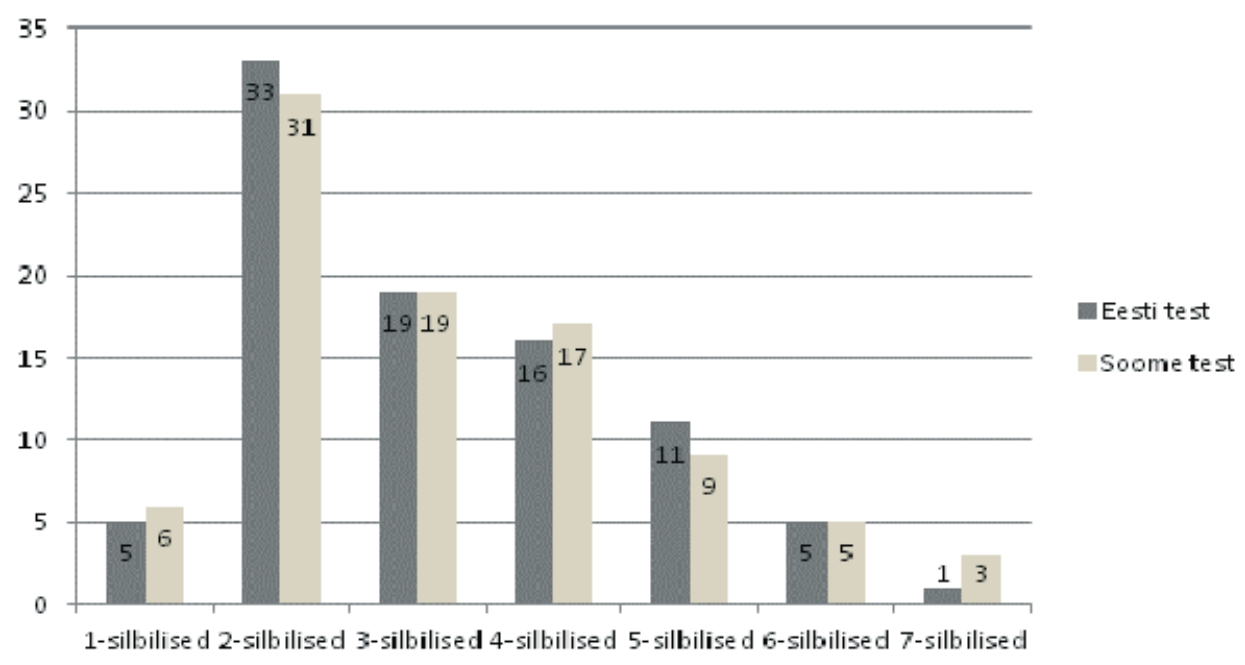

Joonis 1. Eesti- ja soomekeelse sõnaloendi lugemise testi sõnade jaotumine silpide arvu alusel

Eesti ja soome testisõnad olid sarnased ka sõnaosade arvu poolest: mõlemas testis olid valdavad lihtsõnad (vastavalt 70 ja 73 sõna), kuid esines ka kahest (18 ja 16 sõna) ning kolmest osast ( 2 ja 1 sõna) koosnevaid liitsõnu, $\chi^{2}(2)=0,51 ; p=0,77$. Seega, eesti ja soome sõnaloendi lugemise testi sõnad olid pikkuselt sarnased nii tähtede, silpide kui ka sõnaosade arvu poolest.

Sõnade silbistruktuuri võrdlemiseks silbitasime kõik testisõnad ja jaotasime silbid lahtisteks, kinnisteks ning häälikuühendiga silpideks. Iga sõna puhul summeerisime kõik sama tüüpi silbid (nt broilerid: üks häälikuühendiga, üks lahtine, üks kinnine silp). Ülevaadet kõikide testisõnade silbilise koostise kohta (iga silbitüübi osas eraldi) vt tabel 2. Eesti ja soome testisõnade jaotumist vastavat tüüpi silpide arvu alusel võrdlesime hii-ruut-testiga iga silbitüübi osas. Kõigi kolme silbitüübi osas oli sõnade jaotuvus sarnane (lahtised silbid: $\chi^{2}(6)=5,99, p=0,42$; kinnised silbid: $\chi^{2}(4)=4,97, p=0,29$; häälikuühendiga silbid: $\left.\chi^{2}(2)=0,96, p=0,62\right)$.

Lisaks võrdlesime testisõnade häälikkoostist, st kas sõna sisaldab häälikuühendit või mitte, sest silbistruktuuri analüüs ei võimalda määrata kõikide häälikuühendite arvu, kuna sageli jaotub konsonantühend mitme silbi vahel (nt ee tüh/jen/da/tud, sm kor/tis/tot). Analüüsil selgus, et eesti ja soome testisõnad jaotusid häälikuühendite arvu alusel sarnaselt, $\chi^{2}(4)=7,56 ; p=0,11$ (vt joonis 2). 
Tabel 2. Eesti- ja soomekeelse sõnaloendi lugemise testi sõnade jaotumine lahtiste, kinniste ja häälikuühendiga silpide arvu alusel

\begin{tabular}{|l|l|c|c|c|c|c|c|c|c|}
\hline \multirow{2}{*}{ Silbi tüüp } & \multirow{2}{*}{ Testi keel } & \multicolumn{7}{|c|}{ Sõnade arv } & \multirow{2}{*}{ Kokku } \\
\cline { 3 - 11 } & & 0 silpi & 1 silp & 2 silpi & 3 silpi & 4 silpi & 5 silpi & 6 silpi & \\
\hline \multirow{2}{*}{ Lahtine } & eesti & 25 & 29 & 22 & 7 & 7 & - & - & 90 \\
\cline { 2 - 11 } & soome & 17 & 35 & 23 & 8 & 4 & 2 & 1 & 90 \\
\hline \multirow{2}{*}{ Kinnine } & eesti & 23 & 35 & 18 & 13 & 1 & - & - & 90 \\
\cline { 2 - 10 } & soome & 35 & 23 & 18 & 13 & 1 & - & - & 90 \\
\hline $\begin{array}{l}\text { Hääliku- } \\
\text { ühendiga }\end{array}$ & eesti & 51 & 30 & 9 & - & - & - & - & 90 \\
\cline { 2 - 10 } & soome & 47 & 36 & 7 & - & - & - & - & 90 \\
\hline
\end{tabular}

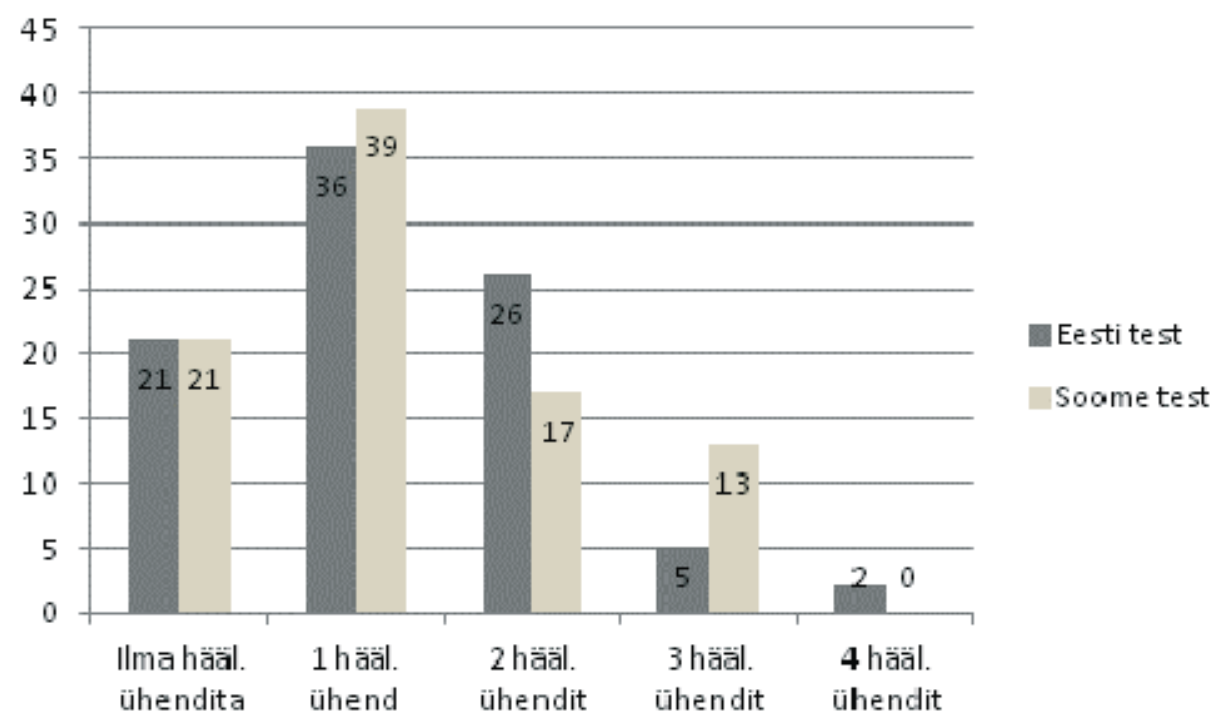

Joonis 2. Eesti- ja soomekeelse sõnaloendi lugemise testi sõnade jaotumine häälikuühendite arvu alusel

\subsection{2. Üliõpilaste testitulemused}

Soome ja eesti üliõpilaste testitulemused (vt tabel 3) olid loetud sõnade koguhulga ja õigesti loetud sõnade osas sarnased: t-testi tulemused olid vastavalt $t(58)=1,20$, $p=0,24$, ja $t(58)=1,49, p=0,14$. Sõnade lugemisel tegid eesti üliõpilased soome tudengitega võrreldes siiski rohkem vigu $(t(58)=4,06, p<0,001)$. Testi esimeste sõnade lugemisel tehti mõlemas keeles vigu harva, erinevus ilmnes keerukamate sõnade puhul, kus eesti tudengid tegid vigu oluliselt sagedamini (nt sõnade harutaksin $\left(2^{\prime}\right)$, padrikus $\left(2^{\prime}\right)$, professorid $\left(2^{\prime}\right)$, kandikutelt $\left(2^{\prime}\right)$, rannikuil $\left(2^{\prime}\right)$ lugemisel) kui soome tudengid. Viimased eksisid vaid sõnade vaari ( $\left.1^{\prime}\right)$, lakritsi ( $\left.1^{\prime}\right)$ ja vingahdus $\left(1^{\prime}\right)$ lugemisel. Eestikeelses testis tegi lugemisvigu kokku 16 üliõpilast, soomekeelses testis eksis vaid kolm testitavat. 
Tabel 3. Eesti ja soome üliõpilaste sõnalugemistestide tulemused: aritmeetilised keskmised ja standardhälbed (sulgudes)

\begin{tabular}{|l|l|c|c|c|c|}
\hline \multicolumn{1}{|c|}{ Test } & \multicolumn{1}{|c|}{ Keel } & $\begin{array}{c}\text { Sõnade } \\
\text { koguhulk }\end{array}$ & $\begin{array}{c}\text { Õigesti } \\
\text { loetud sõnad }\end{array}$ & $\begin{array}{c}\text { Valesti } \\
\text { loetud sõnad }\end{array}$ & $\begin{array}{c}\text { Vahele } \\
\text { jäetud sõnad }\end{array}$ \\
\hline \multirow{2}{*}{$\begin{array}{l}\text { Sõnaloendi } \\
\text { lugemise test }\end{array}$} & eesti $(n=30)$ & $68,13(10,07)$ & $67,20(10,12)$ & $0,93(1,08)$ & - \\
\cline { 2 - 6 } & soome $(n=30)$ & $71,43(11,27)$ & $71,33(11,29)$ & $0,10(0,31)$ & - \\
\hline $\begin{array}{l}\text { Sõnade ära- } \\
\text { tundmise test }\end{array}$ & eesti $(n=30)$ & $60,80(10,63)$ & $60,17(10,63)$ & $0,23(0,50)$ & $0,40(1,07)$ \\
\cline { 2 - 6 } & soome $(n=28)$ & $63,93(9,22)$ & $62,93(8,78)$ & $0,53(0,84)$ & $0,46(1,37)$ \\
\hline
\end{tabular}

\subsection{Sõnade äratundmise test}

\subsubsection{Testisõnade keeleline analüüs}

Eesti ja soome testisõnade sagedusanalüüsi viisime mõlema testi puhul läbi nende 80 sõna osas, mis vastasid pildile. Sagedussõnastikes oli esindatud eesti testisõnadest 61 ja soome testisõnadest 47 sõna. Sõnade keskmised järjekorranumbrid sagedusloendites olid eesti ja soome testis vastavalt 5055,9 $(S D=4165,6)$ ja 4331,6 $(S D=2719,3)$ ning erinevus testide vahel ei olnud statistiliselt oluline, $t(106)=1,03$, $p=0,30$. Sarnaselt sõnaloendi lugemise testiga jaotasime testisõnad sageduse alusel viide kategooriasse (vt tabel 1). Hii-ruut-testi tulemused näitasid, et eesti ja soome testi sõnad jaotusid vastavatesse kategooriatesse sarnaselt, $\chi^{2}(3)=3,82, p=0,28$. Sagedussõnastikest ei leia laste jaoks ilmselgelt tuttavaid testisõnu (ee silmad, lilled, konnad; sm pupu, muki, farkut). Lisaks ei kajastunud sagedussõnastikes mitmed eesti ja soome keeles sagedased liitsõnad (ee vanaema, tuletikud, piparkoogid; sm kumipatja, tulitikku, piparkakku).

Testisõnade pikkust võrdlesime kõikide sõnade osas (mõlemas testis 320 sõna) tähtede, silpide ning sõnaosade arvu alusel. Keskmine sõna pikkus tähtedes oli testides väga sarnane: eesti testis $6,1(S D=1,6)$ ja soome testis $6,1(S D=1,8)$, $t(638)=0,40, p=0,69$. Sarnaselt jaotusid sõnad ka silpide arvu alusel (vt joonis 3 ), $\chi^{2}(4)=8,15, p=0,09$.

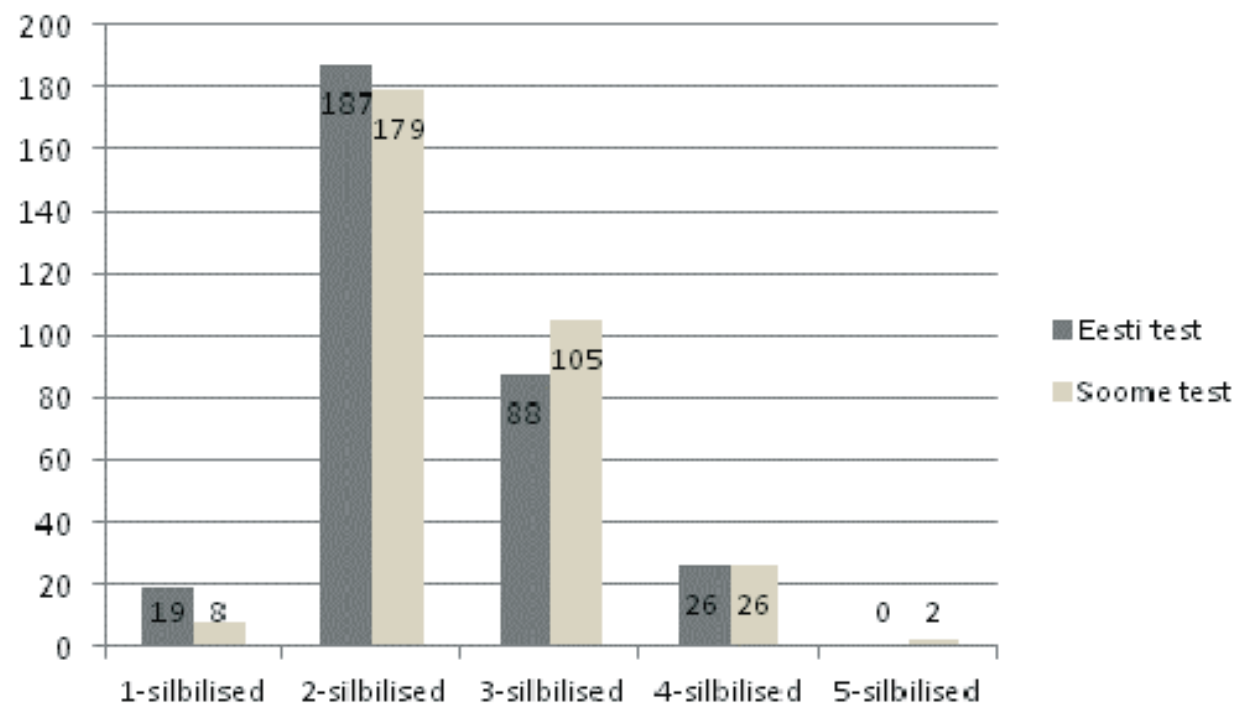

Joonis 3. Eesti- ja soomekeelse sõnade äratundmise testi sõnade jaotumine silpide arvu alusel 
Eesti ja soome testisõnad olid sarnased ka sõnaosade arvu poolest: mõlemas testis oli enim lihtsõnu (vastavalt 299 ja 292 sõna), vähem esines ka kahest osast koosnevaid liitsõnu (21 ja 28 sõna). Sõnade pikkus sõnaosade arvu alusel testide vahel ei erinenud, $\chi^{2}(1)=1,08, p=0,30$. Sõnade pikkuse osas olid eesti ja soome sõnade äratundmise testid seega sarnased.

Testisõnade silbistruktuuri analüüs, mille käigus võrdlesime lahtiste, kinniste ja häälikuühendiga silpide arvu sõnades, näitas erinevusi eesti ja soome testi vahel (vt tabel 4). Eesti testisõnad sisaldasid oluliselt vähem lahtisi silpe kui soome testi sõnad $\left(\chi^{2}(4)=75,74, p<0,001\right)$, seevastu oli eesti testis enam kinniseid silpe sisaldavaid sõnu $\left(\chi^{2}(3)=49,35, p<0\right.$,001). Häälikuühendit sisaldavate silpidega sõnu oli testides sarnaselt $\left(\chi^{2}(1)=2,60, p=0,11\right)$.

Tabel 4. Eesti- ja soomekeelse sõnade äratundmise testi sõnade jaotumine lahtiste, kinniste ja häälikuühendiga silpide arvu alusel

\begin{tabular}{|c|c|c|c|c|c|c|c|}
\hline \multirow{2}{*}{ Silbi tüüp } & \multirow{2}{*}{ Testi keel } & \multicolumn{5}{|c|}{ Sõnade arv } & \multirow{2}{*}{ Kokku } \\
\hline & & 0 silpi & 1 silp & 2 silpi & 3 silpi & 4 silpi & \\
\hline \multirow{2}{*}{ Lahtine } & eesti & 112 & 101 & 73 & 26 & 8 & 320 \\
\hline & soome & 24 & 141 & 113 & 38 & 4 & 320 \\
\hline \multirow{2}{*}{ Kinnine } & eesti & 90 & 137 & 88 & 5 & - & 320 \\
\hline & soome & 144 & 149 & 26 & 1 & - & 320 \\
\hline \multirow{2}{*}{ Häälikuühendiga } & eesti & 244 & 76 & - & - & - & 320 \\
\hline & soome & 226 & 94 & - & - & - & 320 \\
\hline
\end{tabular}

Sõnade häälikkoostise analüüsimisel võrdlesime kõigepealt lihthäälikutest koosnevate ja häälikuühendeid sisaldavate sõnade sagedust eesti ja soome testis (vt joonis 4). Tulemused näitasid, et eesti ja soome testisõnad jaotusid häälikuühendite arvu alusel sarnaselt, $\chi^{2}(3)=2,23, p=0,53$. Teiseks analüüsisime, mitmes sõnarühmas on õige sõna valikukriteeriumiks häälikupikkus, st mitme sõnarühma puhul tuleb testi sooritajal sõna valikul toetuda vaid sõna lugemisele õige häälikupikkusega. Varieeruva häälikupikkusega sõnade rühmade arv oli testides sarnane (eesti testis 9 ja soome testis 7$), \chi^{2}(1)=0,28, p=0,60$.

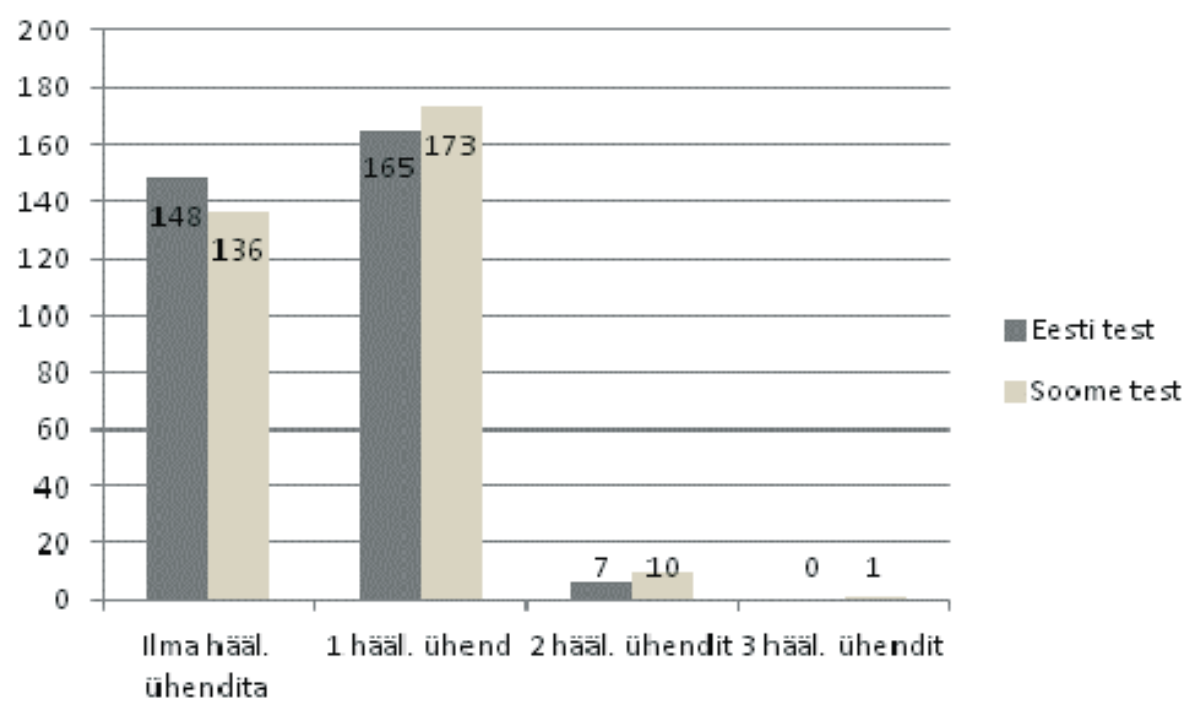

Joonis 4. Eesti- ja soomekeelse sõnade äratundmise testi sõnade jaotumine häälikuühendite arvu alusel 


\subsection{2. Üliõpilaste testitulemused}

Üliõpilaste tulemused sõnade äratundmise testis olid eesti ja soome rühmas küllaltki sarnased (vt tabel 3). Soome testitulemused olid küll mõnevõrra kõrgemad sõnade koguhulga ja õigesti loetud sõnade hulga osas, kuid mitte statistiliselt olulisel määral: t-testi tulemused olid vastavalt $t(56)=1,19, p=0,24$, ja $t(56)=1,08$, $p=0$,29. Lugemisel jäeti ühendamata sarnane hulk pildi-sõna paare $(t(56)=0,20$, $p=0,84)$. Piltide ja sõnade ühendamisel tegid soomlased eestlastega võrreldes mõnevõrra enam vigu, kuid rühmadevaheline erinevus ei olnud statistiliselt oluline $(t(56)=1,67, p=0,10)$.

Tulemuste detailsem analüüs näitas, et eesti testis tegi lugemisvigu kokku kuus üliõpilast, seejuures eksiti viie sõna äratundmisel: sillid pro siilid (2'), killid pro kiilid (2'), ripakil pro rippuma (1'), viski pro veski (1'), varakas pro vaarikas (1'). Soomekeelses testis eksis kokku 10 üliõpilast ning vead jaotusid järgmiselt: pamppu 'kumminui' pro pumppu 'pump' ( $\left.7^{\prime}\right)$, tahti 'takt; tempo' pro tähti 'täht' (2'), silli 'heeringas' pro siili 'siil' ( $\left.2^{\prime}\right)$, nauha 'pael' pro naula 'nael' $\left(1^{\prime}\right)$, hirveä kole' pro hirvi 'põder' ( $\left.1^{\prime}\right)$, apina 'ahv' pro apila 'ristikhein' $\left(1^{\prime}\right)$, mustekala kaheksajalg' pro mustikka 'mustikas' ( $\left.1^{\prime}\right)$. Enamik nimetatud lugemisvigadest peegeldab kiirel lugemisel tehtud dekodeerimisviga, v.a soome testisõnade pamppu-pumppu osas, kus sage eksimine viitab pildil kujutatud objekti ebaselgusele.

\subsubsection{Laste intervjuude tulemused}

Kuna testide sooritamise ajal ei ole võimalik registreerida laste kõhklusi ja kahtlusi - näha on vaid lõplikud valikud-, viisime läbi testid ja intervjuud üheksa eesti ja soome lapsega (vt eespool 5.2), kellel paluti lisaks sõnade ettelugemisele kommenteerida oma kõhklusi. Laste testisooritused ja intervjuud andsid olulist lisateavet võimalike sõnade lugemisel ja piltide tajumisel ettetulevate probleemide kohta.

Eesti ja soome laste testisooritused ja intervjuud näitasid, et valdav osa pildisõna paare ühendati suuremate raskusteta. Nooremad lapsed tegid lugemisel siiski rohkem vigu, mis kohati raskendas pildi juurde õige sõna valimist, vt näited (1)-(3).

(1) (ee) Peep: ratast kujutavale pildile sobivat sõna (radas, rattas, ratas, ruttas $)^{9}$ valides loeb ratas pro radas, mistõttu valib esialgu sõna radas. Suunamise peale valib õige sõna.

(2) (ee) Iti: kahte kassi kujutavale pildile sobiva sõna (kassad, kaasad, kasid, kassid) valimisel loeb kassid pro kasid ja kassid (III v) pro kassid (II v) ning kahtleb, kumb sõna on õige.

(3) (ee) Ats: pildi juurde sobivat sõna (kutsikad, kalurid, keeravad, kartulid) valides loeb kalurid pro kartulid. Kui testija kordab lapse valitud sõna, märkab Ats oma viga. Testija küsimusele, miks ta valis sõna kalurid, vastab, et ei lugenud sõna lõpuni.

Näidetes (4)-(6) teevad lapsed lugemisel vea, kuid see ei takista õige sõna ühendamist pildiga. 
(4) (sm) Henna: loeb katkera pro katketa, kuid see ei sega õige sõna ühendamist pildiga (katketa, kihara, kitara, kätkeä).

(5) (ee) Hans: õiget pilti (randa, panda, pandi, anda) valides küsib, mis see randa (II v) on?

(6) (ee) Hans: enne sõna valimist (huugad, huuled, huikad, huilgad) küsib, mis sõna see huugad (II v) on?

Näited (5)-(6) osutavad sellele, et häälikupikkuse varieerumine eesti keeles teeb lugemise raskemaks seetõttu, et sõnarühma sees mõjutab sõna lugemist ka eelnevate ja järgnevate sõnade häälikute pikkus. Kuna antud sõnades (randa, huugad) kirjapilt hääldust täpselt ei fikseeri, siis võib see aeglustada lugemise protsessi.

Lisaks kirjeldatud juhtudele, kus sõna valikut raskendasid dekodeerimisprobleemid, esines testides ka pilte, millel kujutatud objekti lapsed ei tundnud (7) või oli mõni pildi kõrval pakutud sõnadest lapse jaoks võõras, nagu näites (8) Iti jaoks sõrnik ja sõrmik. Näites (9) tunnistab Kati, et ta ei tea sõna kallur tähendust. Henna valis küll pakutud variantidest õige sõna pildi juurde (10), kuid ütles, et ei tea sõna pamppu tähendust.

(7) (sm) Marja: enne sõna valimist (höylä, höyry, nöyrä, hölmö) küsib höövlit kujutava pildi kohta, mis see on.

(8) (ee) Iti: sõrmikut kujutava pildi juurde sõna (sõrnik, sõrmik, sõrmus, sõ̃rik) valimisel loeb sõnad õigesti, kuid ei oska valida, kas õige sõna on sõrnik või sõrmik. Testija suunava küsimuse peale, kuidas nimetatakse kinnast, millel on sõrmed küljes, valib õige sõna.

(9) (ee) Kati: kalluri pildi juurde sobiva sõna (kalur, kallur, kallis, kaalus) valikul ütleb, et õige sõna on kallur, aga ta ei tea, mida see sõna tähendab.

(10) (sm) Henna: valis pildi kõrvalt ( õige sõna, kuid tunnistas intervjueerijale, et ei tea, mis see pamppu on.

Laste kommentaarid osutavad sellele, et mõnel pildil kujutatu (soome testis tomat, kurk, pump, eesti testis kohviuba) ei olnud piisavalt selgelt ja ühemõtteliselt joonistatud:

(11) (sm) Jussi leiab pildiga sobiva sõna, kuid kommenteerib seejärel tomati pilti, et see ei ole tomati moodi, see on pigem kõrvitsa moodi.

(12) (sm) Jussi kommenteerib kurgi pilti: kurk on suvikõrvitsa moodi.

(13) (sm) Oskari kommentaar (jalgratta)pumba pildile on, et see oleks nagu pipett.

(14) (ee) Peep ütleb (kohvik, kohviuba, koolimaja, kohvitama) õiget sõna valides, et sellest pildist küll aru ei saa, tundub nagu hamburger või kohv.

Laste intervjuude põhjal selgus, et nii eesti kui soome sõnavaliku testid on koostatud lapsele arusaadavalt, kuid mõlemas testis on mõned problemaatilised sõna ja pildi ühendamise juhud. 


\section{Kokkuvõte}

Analüüsisime võrdlevalt kahte eesti- ja soomekeelset sõnalugemistesti - sõnaloendi lugemise testi ja sõnade äratundmise testi. Võrreldes teste meetoditriangulatsiooni (testide keeleline analüüs, täiskasvanud lugejate testisoorituste ja laste intervjuude analüüs) abil, püüdsime hinnata lugemistestide vastavust ja arendada sellega lugemistestide võrdlusmeetodeid. Mitme meetodi paralleelne kasutamine võimaldab nii eri- kui ka samakeelsete lugemistestide ekvivalentsust hinnata mitmekülgsemalt kui vaid ühte meetodit rakendades.

Sõnaloendi lugemise testide keeleline analüüs näitas, et eesti- ja soomekeelne test on sarnased nii sõnade sageduse, pikkuse kui ka hääliku- ja silbistruktuuri poolest. Üliõpilaste testisooritused viitasid aga eesti testi sõnade mõnevõrra suuremale keerukusele. Nimelt lugesid eesti üliõpilased antud ajalimiidi jooksul küll ligikaudu sama palju sõnu kui soome tudengid ja ka õigesti loetud sõnade keskmine hulk oli sarnane, kuid nad tegid rohkem lugemisvigu. Erinevus vigade arvus viitab eesti testi mõnevõrra kõrgemale raskusastmele, mille põhjused testide keelelisel analüüsil ei selgunud. On võimalik, et eesti test sisaldas siiski rohkem keeles harva esinevaid sõnu - nimelt kajastasid kasutatud sõnade sagedusloendid vähem kui poolt testisõnadest. Teine põhjus võib olla ka mõni siinses artiklis käsitlemata aspekt (näiteks sõnade morfoloogiline koostis), mis võis mõjutada sõnade lugemise õigsust. Kolmas võimalik põhjus võib seisneda keelelistes iseärasustes: kuna eesti keeles on sõnad üldiselt lühemad kui soome keeles, aga testisõnad olid pikkuselt sarnased, siis võib oletada, et eesti lugeja jaoks valmistab väga pikkade sõnade lugemine mõnevõrra suuremaid raskusi kui sama pikkusega sõnade lugemine soome keeles. Eesti testi sooritamise võib muuta raskemaks ka asjaolu, et paljude sõnade puhul tuleb lähtuvalt sõna tähendusest valida lugemisel õige sõnavälde (nt kuula, purgid), mida soomekeelse testi sooritajal teha ei tule. Nimetatud keeleline iseärasus ei pruugi oluliselt mõjutada kogenud lugejate testisooritust, küll aga raskendab see dekodeerimise protsessi lugemaõppimise alguses.

Sõnade äratundmise teste võrdlesime testisõnu keeleliselt analüüsides, üliõpilaste testitulemuste ja laste intervjuude põhjal. Testide keeleline analüüs näitas, et eesti- ja soomekeelne test olid väga sarnased sõnade sageduse ja pikkuse poolest. Sõnade silbistruktuuri analüüsil selgus, et eesti testi sõnades oli soome testi sõnadega võrreldes mõnevõrra vähem lahtisi ja rohkem kinniseid silpe. Häälikuühendeid oli testisõnades siiski sarnasel hulgal. Kuna lahtisi silpe peetakse lugemise seisukohalt lihtsamaks kui kinniseid ja häälikuühendeid sisaldavaid silpe (Seymour jt 2003), siis võib oletada, et eesti testi sooritamine võib valmistada mõnevõrra suuremaid raskusi lugemisoskuse arengu algetapil kui soome testi sooritamine samas vanuses.

Üliõpilaste sooritused sõnade äratundmise testis osutasid testide suurele sarnasusele nii loetud sõnade koguhulga, õigesti loetud sõnade kui ka valesti loetud sõnade osas. Mõnevõrra rohkem eksisid küll soome üliõpilased, tulemuste täpsem analüüs osutas ühele problemaatilisele pildile (rattapump) ja raskustele vastava sõna valikul. Laste testisooritused ja intervjuud näitasid, et valdav osa pildi-sõna paare ühendati suuremate raskusteta, nooremad lapsed eksisid sõnade lugemisel enam ning kõhklesid seetõttu sagedamini ka sõnale vastava pildi valikul. Mõlemas testis oli siiski ka sõnu, mille tähendust lapsed ei teadnud ja pilte, millel kujutatut 
ei tuntud ära või selles kaheldi. Laste intervjuude põhjal võib siiski väita, et nii eesti kui soome sõnade äratundmise testi sõnad ja pildid on lastele mõistetavad ning suuri erinevusi kahe testiversiooni vahel ei esine.

Lõpetuseks võib öelda, et artiklis analüüsitud eesti-ja soomekeelset sõnaloendi lugemise testi ja sõnade äratundmise testi võib kasutada võrreldavate hindamisvahenditena keeltevahelistes uuringutes. Siiski ei saa neid pidada identseteks testideks eesti ja soome keeles, seda osalt mõningaste erinevuste tõttu testides endas ning osalt keeleliste iseärasuste tõttu. Testide tõlkimisel ja kohandamisel ühest keelest teise on küll oluline, et testid oleksid võimalikult sarnased, kuid erikeelsete ajapiiranguga sõnalugemistestide identsust on ülimalt keerukas, kui mitte võimatu saavutada. Nimelt on sõnade lugemist mõjutavad keelelised faktorid lugemaõppimise eri faasides keeleti erinevad ning testid, mida saab pidada identseteks ühe lugejarühma (näiteks algajate lugejate) oskuste võrdlemiseks, ei pruugi seda olla teise lugejarühma (näiteks kogenumate lugejate) puhul.

\section{Viidatud kirjandus}

Arffman, Inga 2010. Equivalence of translations in international reading literacy studies. Scandinavian Journal of Educational Research, 54, 37-59.

Aro, Mikko 2004. Learning to Read: The Effect of Orthography. https://jyx.jyu.fi/dspace/ bitstream/handle/123456789/13355/9513917223.pdf?sequence = 1 (14.09.2012).

Aro, Mikko; Wimmer, Heinz 2003. Learning to read: English in comparison to six more regular orthographies. - Applied Psycholinguistics, 24 (4), 621-635. http://dx.doi. org/10.1017/S0142716403000316

Cain, Kate 2010. Reading Development and Difficulties. West Sussex: BPS Blackwell.

Cohen, Louis; Manion, Lawrence; Morrison, Keith 2000. Research Methods in Education. 5th ed. London: Routledge Falmer.

De Luca, Maria; Borrelli, Marta; Judica, Anna; Spinelli, Donatella; Zoccolotti, Pierluigi 2002. Reading words and pseudowords: An eye movement study of developmental dyslexia. Brain and Language, 80 (3), 617-626. http://dx.doi.org/10.1006/brln.2001.2637

Dürrwächter, Ute; Sokolov, Alexander N.; Reinhard, Jens; Klosinski, Gunther; TrauzettelKlosinski, Susanne 2010. Word length and word frequency affect eye movements in dyslexic children reading in a regular (German) orthography. - Annals of Dyslexia, 60 (1), 86-101. http://dx.doi.org/10.1007/s11881-010-0034-9

EKK 2007 = Erelt, Mati; Erelt, Tiiu; Ross, Kristiina 2007. Eesti keele käsiraamat. Kolmas, täiendatud trükk. Tallinn: Eesti Keele Sihtasutus.

Hakulinen, Auli; Vilkuna, Maria; Korhonen, Riitta; Koivisto, Vesa; Heinonen, Tarja-Riitta; Aho, Irja 2004. Iso suomen kielioppi. SKS:n toimituksia 950. Helsinki: Suomalaisen Kirjallisuuden Seura.

Hint, Mati 2004. Eesti keele foneetika ja morfoloogia. Viies, ümbertöötatud trükk. Tallinn: Avita.

Hint, Mati 1988. Eesti ilukirjanduskeele statistiline fonotaktika. Silbistruktuuri elemendid. Tallinn: E. Vilde nim Tallinna Pedagoogiline Instituut.

Hoover, Wesley A.; Gough, Philip B. 1990. The simple view of reading. - Reading and Writing, 2 (2), 127-160. http://dx.doi.org/10.1007/BFo0401799

Hutzler, Florian; Wimmer, Heinz 2004. Eye movements of dyslexic children when reading in a regular orthography. - Brain and Language, 89 (1), 235-242. http://dx.doi. org/10.1016/S0093-934X(03)00401-2

Häyrinen, Taru; Serenius-Sirve, Silve; Korkman, Marit 1999. Lukilasse. Helsinki: Psykologien kustannus. 
Hyönä, Jukka; Olson Richard K. 1995. Eye fixation patterns among dyslexic and normal readers: Effects of word length and word frequency. - Journal of Experimental Psychology: Learning, Memory, and Cognition, 21 (6), 1430-1440. http://dx.doi. org/10.1037/0278-7393.21.6.1430

Kikas, Eve 2006. School psychology in Estonia. - Shane R. Jimerson, Thomas Oakland, Peter T. Farrell (Eds.). The Handbook of International School Psychology. California: Sage Publications, 91-102.

Landerl, Karin; Wimmer, Heinz 2008. Development of word reading fluency and spelling in a consistent orthography: An 8-year follow-up. - Journal of Educational Psychology, 100 (1), 150-161. http://dx.doi.org/10.1037/0022-0663.100.1.150

Lerkkanen, Marja-Kristiina 2007. Lugema õppimine ja õpetamine alus- ja algõpetuses. Tartu: Tartu Ülikooli Kirjastus.

Lindeman, Johanna 1998. ALLU-Ala-asteen lukutesti. Åbo: Åbo Akademis förlag.

Oakhill, Jane; Cain, Kate 2007. Introduction to comprehension development. - Kate Cain, Jane Oakhill (Eds.). Children's Comprehension Problems in Oral and Written Language. New York: The Guilford Press, 1-40.

Perfetti, Charles A. 1994. Psycholinguistics and reading ability. - Morton Ann Gernsbacher (Ed.). Handbook of Psycholinguistics. San Diego: Academic Press, 849-894.

Priya, Kanu; Wagner, Richard K. 2009. The roles of fluent decoding and vocabulary in the development of reading comprehension. - Richard K. Wagner, Christopher Schatschneider, Caroline Phytian-Sence (Eds.). Beyond Decoding: The Behavioral and Biological Foundations of Reading Comprehension. New York: The Guilford Press, 124-139.

Remes, Hannu 2009. Muodot kontrastissa: Suomen ja Viron vertailevaa taivutusmorfologiaa. Acta Universitatis Ouluensis B. Humaniora 90. Oulu: Oulun yliopisto.

Seymour, Philip H. K.; Aro, Mikko; Erskine, Jane M. 2003. Foundation literacy acquisition in European orthographies. - British Journal of Psychology, 94 (2), 143-174. http:// dx.doi.org/10.1348/000712603321661859

Soodla, Piret 2012. Teachers' judgments of monolingual and bilingual students' reading skills: Child-, class-, and teacher-related factors. - Aaro Toomela, Eve Kikas (Eds.). Children Studying in a Wrong Language: Russian Speaking Children in Estonian School. Twenty Years after the Collapse of the Soviet Union. Frankfurt am Main: Peter Lang, 123-151.

Soodla, Piret; Kikas, Eve 2010. Teachers' judgment of students' reading difficulties and factors related to its accuracy. - Aaro Toomela (Ed.). Systemic Person-Oriented Study of Child Development in Early Primarly School. Frankfurt am Main: Peter Lang, 73-94.

Tong, Xiuli; Deacon, S. Hélène; Kirby, John R.; Cain, Kate; Parrila, Rauno 2011. Morphological awareness: A key to understanding poor reading comprehension in English. - Journal of Educational Psychology, 103, 523-534. http://dx.doi.org/10.1037/a0023495

Torppa, Minna; Tolvanen, Asko; Poikkeus, Anna-Maija; Eklund, Kenneth; Lerkkanen, Marja-Kristiina; Leskinen, Esko; Lyytinen, Heikki 2007. Reading development subtypes and their early characteristics. - Annals of Dyslexia, 57 (1), 3-37. http://dx.doi. org/10.1007/s11881-007-0003-0

\section{Võrgumaterjalid}

Eesti kirjakeele sagedussõnastik. http://www.cl.ut.ee/ressursid/sagedused1/ (20.09.2012). Suomen sanomalehtikielen taajuussanasto. http://www.csc.fi/tutkimus/alat/kielitiede/ taajuussanasto-B9996/view (20.09.2012). 
Piret Soodla (Tallinna Ülikool) uurimistöö valdkonnad on suulise ja kirjaliku kõne areng, kõnearengu ja lugemisoskuse hindamine.

piret.soodla@tlu.ee

Maigi Vija (Tartu Ülikool) on uurinud esimese keele omandamist, sh morfoloogiat ja pronoomenikasutust.

maigi.vija@ut.ee

Renate Pajusalu (Tartu Ülikool) uurimistöö valdkonnad on semantika ja pragmaatika, eriti referentsiaalsusega seotu. Uurinud on ka esimese ja teise keele omandamist.

renate.pajusalu@ut.ee 


\section{COMPARISON OF ESTONIAN AND FINNISH WORD READING TESTS}

Piret Soodla ${ }^{1}$, Maigi Vija ${ }^{2}$, Renate Pajusalu²

${ }^{1}$ Tallinn University, ${ }^{2}$ University of Tartu

In the present study two word-reading tests in Estonian and Finnish are compared. The word- list reading test assesses decoding speed and accuracy. The word-recognition test assesses fluency and accuracy of word recognition in the reading process. The study had two aims. The first was to evaluate the comparability of the reading tests in Estonian and Finnish. The second aim was to contribute an appropriate method for comparing word reading tests. The comparative analysis of the two tests involved multiple methods: linguistic analysis, analyses of adult readers' and children's test performances and children's interviews. The results point mainly to similarities but also to some differences between the Estonian and Finnish tests.

Keywords: testing, assessment, reading skills, Estonian, Finnish 